\title{
Checklist and Distribution of Calanoida (Crustacea: Copepoda) in Kazakhstan (Central Asia)
}

\author{
Elena Krupa ${ }^{1,2}$ (D) and Moldir Aubakirova ${ }^{3, *}$ \\ 1 Institute of Zoology, Almaty 050060, Kazakhstan; elena_krupa@mail.ru \\ 2 Kazakh Agency of Applied Ecology, Almaty 050010, Kazakhstan \\ 3 Faculty of Biology and Biotechnology, Al-Farabi Kazakh National University, Almaty 050040, Kazakhstan \\ * Correspondence: judo_moldir@mail.ru; Tel.: +7-727-269-4876
}

check for updates

Citation: Krupa, E.; Aubakirova, M. Checklist and Distribution of Calanoida (Crustacea: Copepoda) in Kazakhstan (Central Asia). Water 2021, 13, 2015. https://doi.org/ 10.3390/w13152015

Academic Editor: Genuario Belmonte

Received: 21 June 2021

Accepted: 19 July 2021

Published: 23 July 2021

Publisher's Note: MDPI stays neutral with regard to jurisdictional claims in published maps and institutional affiliations.

Copyright: (c) 2021 by the authors Licensee MDPI, Basel, Switzerland. This article is an open access article distributed under the terms and conditions of the Creative Commons Attribution (CC BY) license (https:// creativecommons.org/licenses/by/ $4.0 /)$

\begin{abstract}
This work aims to analyze the zoogeographic distribution of Calanoida in Kazakhstan. Kazakhstan belongs to the Palaearctic region, and its territory is ascribed to the European-Siberian and Nagorno-Asian biogeographical subregions. The European-Siberian subregion includes the Volga-Ural, Irtysh, and Turkestan-Aral provinces. The Balkhash province belongs to the NagornoAsian subregion. Studies of the Calanoida fauna were carried out between 1997 and 2019. For this purpose, 7250 zooplankton samples were taken in 130 different water bodies. Findings of 26 species of Calanoida have been documented. The richest in species composition (20) is the Calanoida fauna of the Irtysh province. Ten Calanoida species have been recorded in the Volga-Ural province, 8 in the Turkestan-Aral province, 7 in the Balkhash province, and 5 in the Ponto-Caspian region. The distribution of the species richness of the order is determined by a complex of climatic factors, including the density of the hydrographic network, a variety of hydrochemical conditions, and accidental acclimatization of species. Far Eastern species (Sinodiaptomus sarsi, Neutrodiaptomus incongruens, Neodiaptomus schmackeri) entered the inland water bodies of Kazakhstan, most likely through the introduction of non-native fish species. The Black Sea species Acartia tonsa and Calanipeda aquaedulcis were introduced into the Caspian Sea with ballast waters. Three autochthonous species (Limnocalanus macrurus, Eurytemora grimmi, Eurytemora minor), formerly inhabiting the Caspian Sea, can now be considered extinct. Acanthodiaptomus denticornis, Arctodiaptomus (R.) salinus, Phyllodiaptomus blanci, and Eudiaptomus graciloides are widespread in the region. Endemic species (Gigantodiaptomus irtyshensis, Arctodiaptomus naurzumensis) and species are new for Kazakhstan (Diaptomus (Chaetodiaptomus) mirus, Eudiaptomus transylvanicus, Arctodiaptomus dentifer, A. (Rh.) ulomskyi were found in small waterbodies; they are known only from single occurrence sites as well as Eurytemora caspica. The last one was described from the northern part of the Caspian Sea, in the coastal zone. Further research into small water bodies that are poorly studied may expand our knowledge of the diversity of Calanoida in Kazakhstan. Calanoida fauna of Kazakhstan was closest to the fauna of countries with a continental climate and most strongly differed from countries with subtropical and Mediterranean types of climates.
\end{abstract}

Keywords: Calanoida; Acartiidae; Pseudodiaptomidae; Centropagidae; Diaptomidae; Temoridae; species richness; distribution; zoogeographic provinces

\section{Introduction}

Calanoida is the most ancient group of aquatic invertebrates and plays an essential role in transferring energy from lower to higher trophic levels [1-4]. About 2000 Calanoida species are known in the world fauna, of which 610 species inhabit continental water bodies $[4,5]$. The distribution of the number of species among individual families of the order is not known precisely. For example, within Diaptomidae from 449 [6] to 515 species [7], within Centropagidae from 79 to 81 species. The lack of accurate data on the species richness and zoogeographic distribution of Calanoida [6,7] is associated with insufficient 
knowledge of the fauna of certain regions [8], ongoing description of new species [9-13], as well as invasions of species out of their natural distribution ranges.

As well as in some other regions $[8,14]$, information on the Calanoida fauna in Kazakhstan is incomplete. According to the literature, 25 species of diaptomids were known in Kazakhstan [15], which was compiled only based on faunistic finds [16-21], without their documentary confirmation. Later articles provided drawings and descriptions of species new to the region-Arctodiaptomus (Rhabdodiaptomus) ulomskyi Chechura, Neolovenula alluaudi (Guerne and Richard) [22,23], Neodiaptomus schmackeri (Poppe and Richard) [23], Diaptomus (Chaetodiaptomus) mirus Lilljeborg in Guerne [24], as well as species new to science-Arctodiaptomus (Arctodiaptomus) naurzumensis Stepanova [9], Gigantodiaptomus irtyshensis Krupa and Stuge [24], Eurytemora caspica Sukhikh and Alekseev [13].

The purpose of this work is to analyze the composition of the Calanoida fauna and the zoogeographic distribution of the species on the territory of Kazakhstan based both on unpublished records of species registered between 1997 and 2019, and verified occurrences reported in the works $[9,23,24]$.

\section{Materials and Methods}

\subsection{Study Site Description}

The climate of most parts of Kazakhstan is continental, arid, and semi-arid, with cold winters and hot summers [25]. The average annual sunshine duration is $2000-3000 \mathrm{~h}$. The average annual air temperature is $+5.5^{\circ} \mathrm{C}$. In the southern parts, it reaches $+15.8^{\circ} \mathrm{C}$. Most of the territory is characterized by a huge difference between the maximum (up to $+42^{\circ} \mathrm{C}$ ) and minimum air temperatures (up to $-57.2^{\circ} \mathrm{C}$ ). In most of the territory, the average annual precipitation reaches $100-500 \mathrm{~mm}$, in the north of the country- $350-650 \mathrm{~mm}$, in mountainous areas up to $900-1200 \mathrm{~mm}$. Most of the rainfall occurs in spring and early summer. The driest months are July and August. In mountainous areas, precipitation falls all year round.

The climatic features of the territory cause high temperatures of waters (up to $24-32{ }^{\circ} \mathrm{C}$ in summer), mostly high Total Dissolved Solids (TDS) values (more than $0.3-0.5 \mathrm{mg} / \mathrm{dm}^{3}$ ), and low alkaline to alkaline water properties [23]. Ultra-fresh and freshwater bodies are distributed mainly in the mountainous regions of South, South-East, and East Kazakhstan. A relatively low content of organic substances and nutrients is typical for the water bodies of Kazakhstan [26].

According to zoogeographic zoning [27], most Kazakhstan territory belongs to the Palaearctic zoogeographic region. The European-Siberian subregion is distinguished within its limits, divided into the Volga-Ural, Irtysh, and Turkestan-Aral provinces, and the Nagorno-Asian subregion, represented by the Balkhash province (Figure 1).

The Volga-Ural province includes the basin of the Ural River and water bodies of western Kazakhstan. The hydrographic network is represented mainly by small rivers, permanent and temporary steppe lakes, and ponds, from ultra-fresh to salty waters. There are no large lakes and reservoirs, except for the brackish lake Shalkar with a water area of about $205.8 \mathrm{~km}^{2}$.

Irtysh province occupies a vast territory of Central, Eastern, and Northern Kazakhstan. It includes the basin of the Irtysh River in the east and the territory to the Ural River basin in the west. The largest water bodies are Zaysan and Markakol lakes and Bukhtarma reservoir. There are many small permanent and temporary lakes in the floodplain of the Irtysh River. Fresh and ultra-fresh water bodies prevail in the east. The TDS of water in water bodies in the northern and western parts of the province varies over a vast range-from 0.3 to $300 \mathrm{~g} / \mathrm{dm}^{3}$. 


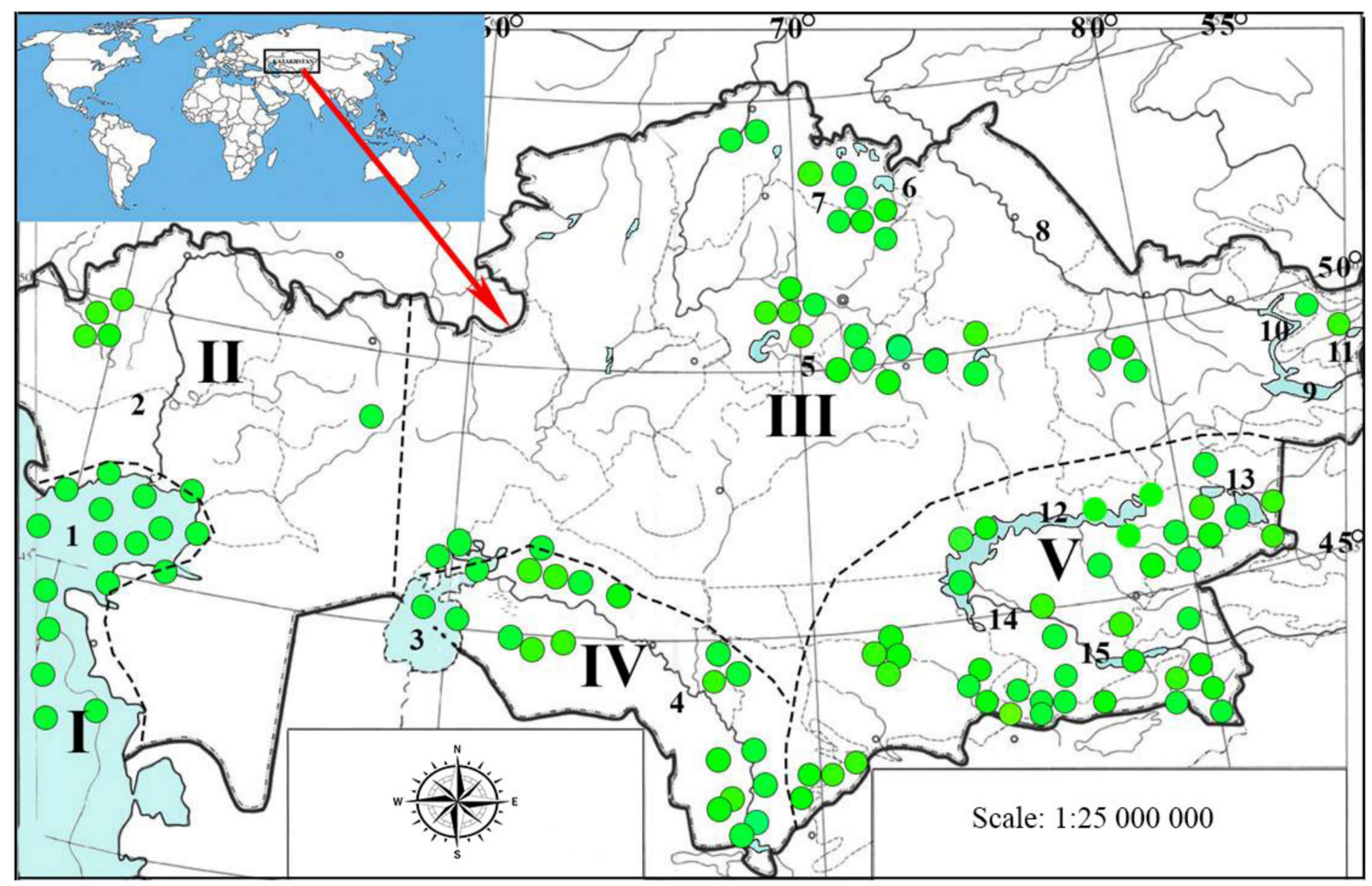

Figure 1. Schematic map of the location of the surveyed water bodies of Kazakhstan and their distribution by zoogeographic provinces and regions: I-Ponto-Caspian region, II-V-European-Siberian subregion of the Palaearctic region, including II-Volga-Ural province, III-Irtysh province, IV-Turkestan-Aral province, V-Balkhash province of the Nagorno-Asian region. Water bodies and systems of water bodies are designated in Arabic numerals: 1. The Caspian Sea, 2. Ural River, 3. The Aral Sea, 4. Syrdarya River, 5. Water bodies of the Nura River Basin, 6. Naurzum Lakes, 7. Shchuchinsko-Borovsk Lakes, 8. River Irtysh, 9. lake Zaysan, 10. Bukhtarma Reservoir, 11. Lake Markakol, 12. Lake Balkhash, 13. Alakol-Sasykol system of lakes, 14. Ili river, 15. Kapshagai reservoir.

Turkestan-Aral province includes the Syrdarya river basin and the Aral Sea. Many reservoirs have been created on the river and its tributaries, including Shardara, Badam, Tasotkel, Ters-Ashchibulak, and others. The TDS of water in the water bodies of the Syrdarya basin varies from 0.5 to $1.5 \mathrm{~g} / \mathrm{dm}^{3}$, in the Aral Sea-from 9.0 to $23.0 \mathrm{~g} / \mathrm{dm}^{3}$.

The Balkhash province unites mountainous regions and basins of the endorheic lakes Balkhash, Alakol, and the $\mathrm{Chu}$, Talas, Ili rivers. In mountainous areas, ultra-fresh and fresh lakes and reservoirs, smaller in area, prevail. Plain lakes Balkhash and Alakol are characterized by an increased content of dissolved salts-from 1.1 to $8.9 \mathrm{~g} / \mathrm{dm}^{3}$. In Sasykkol, Koshkarkol, and Zhalanashkol lakes, TDS water reaches $0.4-1.5 \mathrm{~g} / \mathrm{dm}^{3}$.

The Ponto-Caspian brackish water area includes the Caspian Sea (except for the Kara-Bogaz-Gol Bay). The TDS values vary from $0.5-1.1 \mathrm{~g} / \mathrm{dm}^{3}$ in the zone of influence of the runoff of the Volga and Ural rivers to $9-12 \mathrm{~g} / \mathrm{dm}^{3}$ in the deep part of the Caspian Sea (Middle Caspian Sea).

Zooplankton samples were collected between 1997 and 2019 in 130 water bodies located in different regions of Kazakhstan (Figure 1). The largest are the Caspian and Aral seas, lakes Balkhash, Alakol, Markakol, Sasykkol, Koshkarkol, Zhalanashkol, reservoirs Kapchagai, Shardara, Samarkan, Yntymak, Badam, and Sorbulak (Table 1). Most of the surveyed water bodies have an area of less than $10 \mathrm{~km}^{2}$. In addition to lakes, reservoirs, and temporary reservoirs, samples were taken in the Syrdarya, Ili, Ural, Emba, and Nura rivers, as well as small rivers and springs. 
Table 1. Information about some surveyed water bodies in Kazakhstan.

\begin{tabular}{cccc}
\hline Name & Type of Water Body & Water Area, $\mathbf{k m}^{\mathbf{2}}$ & Maximum Depth, $\mathbf{~}$ \\
\hline Caspian Sea & lake & 390,000 & 1025 \\
Small Aral Sea & lake & 3300 & 18 \\
Balkhash & lake & 18,200 & 34 \\
Tenise & lake & 1590 & 8 \\
Alakol & lake & 2650 & 54 \\
Sasykkol & lake & 736 & 5 \\
Markakol & lake & 455 & 27 \\
Koshkarkol & lake & 120 & 6 \\
Zhalanashkol & lake & 36 & 6 \\
Big Chebachye & lake & 23 & 27 \\
Zhukey & lake & 22 & 3 \\
Shchuchye & lake & 20 & 22 \\
Small Chebachye & lake & 19 & 10 \\
Borovoe & lake & 11 & 6 \\
Kapshagay & reservoir & 1847 & 45 \\
Shardara & reservoir & 725 & 16 \\
Sorbulak & reservoir & 53 & 25 \\
Samarkan & reservoir & 52 & 9 \\
Yntymak & reservoir & 12 & 6 \\
\hline
\end{tabular}

The water bodies are located at altitudes from -27 to $3170 \mathrm{~m}$ above sea level (Table 2). The temperature of the surface water layers in summer varies from 14.9 to $32.0^{\circ} \mathrm{C}$. The total dissolved solids (TDS) in water vary widely. The lowest values of the indicator are typical for mountain lakes and reservoirs with glacial nutrition. A relatively increased TDS is recorded in the endorheic lowland lakes. In the north of the country, there are hyperhaline lakes; their water contains up to $100.0-350.0 \mathrm{~g} / \mathrm{dm}^{3}$ of total dissolved solids.

Table 2. Types of the surveyed water bodies, their altitude above sea level, TDS, and maximum water temperature.

\begin{tabular}{cccc}
\hline Type of Water Body & Altitude Above Sea Level, $\mathbf{~ m}$ & TDS, $\mathbf{g} / \mathbf{d m}^{\mathbf{3}}$ & Water Temperature, ${ }^{\circ} \mathbf{C}$ \\
\hline Caspian Sea & -27 & $0.5-13.0$ & $26.0-28.0$ \\
Aral Sea & 42 & $9.0-23.0$ & $26.0-28.0$ \\
Balkhash & 340 & $0.5-5.5$ & $26.0-28.0$ \\
mountain lakes and reservoirs & $1069-3170$ & $0.03-0.57$ & $12.1-24.1$ \\
water bodies of plains & $33-529$ & $0.21-350.0$ & $14.9-30.0$ \\
mountain rivers & $1078-1986$ & $0.99-0.47$ & $10.1-18.0$ \\
plain rivers & $14-389$ & $0.30-1.20$ & $24.0-32.0$ \\
\hline
\end{tabular}

\subsection{Taxon Sampling and Species Identification}

Zooplankton samples were taken with a Juday plankton net (mesh size $64 \mu \mathrm{m}$ ), with a mouth diameter of $12 \mathrm{~cm}$, by towing it from the bottom to the surface. The filtered water was poured into plastic containers with a volume of $250 \mathrm{~mL}$. Samples were fixed with $40 \%$ formalin to a final concentration of $4 \%$. At each water body, sampling of zooplankton was carried out according to a grid of stations, taking into account one station per $1.5-2.5 \mathrm{~km}^{2}$ of the water surface. In small lakes and reservoirs, 3-5 samples were taken. In large water bodies, the number of collected zooplankton samples varied from 10 to 50 . A total of 7250 zooplankton samples were collected and processed.

For species identification, adult male and female Calanoida were dissected using an MBS-10 microscope (Lytkarino Optical Glass Factory, Moscow, Russia). For each species, temporary slides, photographs, and drawings of identifying features were made. The species identification was carried out using an MCX-300 microscope (Micros, Sankt Veit an der Glan, Austria) according to the identification keys and figures given in monographs [28,29] and articles [13,30-36]. 


\subsection{Statistical Analysis}

We visualized the similarity in Calanoida fauna between different regions by build-ing a dendrogram based on the Bray-Curtis distance. Bray-Curtis Cluster Analysis was done using Primer 5 Software [37].

\section{Results}

The species composition of Calanoida in Kazakhstan is given in Table 3. Overall, that 26 species from 5 families and 18 genera are reliably known in the Calanoida fauna of Kazakhstan (Table 4). The largest number of Calanoida species was found in the Irtysh province (Table 3). The originality of the fauna is associated with the presence of such species as Gigantodiaptomus angularis, G. amblyodon, G. irtyshensis, Eudiaptomus transylvanicus, Arctodiaptomus (A.) naurzumensis, A. (A.) dentifer, A. (R.) acutilobatus. The Volga-Ural province occupies second place in the diversity of diaptomids with the characteristic species Diaptomus (Chaetodiaptomus) mirus and Arctodiaptomus (Rh.) ulomskyi. Calanoida of the Turkestan-Aral and Balkhash provinces are represented by a small number of widespread species. The fauna of Calanoida is the most impoverished in mountainous areas, where only two species were recorded-Eudiaptomus graciloides and Acanthodiaptomus denticornis. To date, only four species have been reliably recorded in the Ponto-Caspian region.

Table 3. Species composition and zoogeographic distribution of Calanoida species in Kazakhstan.

\begin{tabular}{|c|c|c|c|c|c|c|}
\hline \multirow{3}{*}{ Species Name } & \multirow{3}{*}{$\begin{array}{l}\text { Types of } \\
\text { Species }\end{array}$} & \multirow{3}{*}{$\begin{array}{l}\text { Ponto-Caspian } \\
\text { Region }\end{array}$} & \multicolumn{4}{|c|}{ Palaearctic Region } \\
\hline & & & \multicolumn{3}{|c|}{ ES } & \multirow{2}{*}{$\begin{array}{l}\text { NA } \\
\text { BLH }\end{array}$} \\
\hline & & & VU & IRT & TUR-AR & \\
\hline${ }^{4}$ Limnocalanus macrurus Sars & endemic & $+?$ & & & & \\
\hline${ }^{1}$ Calanipeda aquaedulcis Kritch * & Ponto-caspian & + & & & + & \\
\hline${ }^{1}$ Acartia (Acanthacartia) tonsa Dana * & marine & + & & & & \\
\hline${ }^{1}$ Heterocope caspia Sars & endemic & + & & & & \\
\hline${ }^{3}$ Eurytemora velox (Lilljeborg) & cosmopolite & & $+?$ & & & \\
\hline${ }^{1}$ Eurytemora affinis (Poppe) & cosmopolite & & & + & & \\
\hline $\begin{array}{c}{ }^{2} \text { Eurytemora caspica Sukhikh, } \\
\text { Alekseev }\end{array}$ & endemic & + & & & & \\
\hline${ }^{3}$ Eurytemora lacustris (Poppe) & marine & & $+?$ & & & \\
\hline${ }^{4}$ Eurytemora grimmi (Sars) & endemic & $+?$ & & & & \\
\hline${ }^{4}$ Eurytemora minor Sars & endemic & $+?$ & & & & \\
\hline${ }^{1}$ Metadiaptomus asiaticus (Uljanin) & Central-Asian & & & + & & \\
\hline $\begin{array}{c}{ }^{1} \text { Neolovenula alluaudi (Guerne and } \\
\text { Richard) }\end{array}$ & Palaearctic & & + & + & & \\
\hline${ }^{3}$ Diaptomus (Diaptomus) castor (Jurine) & Palaearctic & & & $+?$ & & \\
\hline $\begin{array}{c}{ }^{1} \text { Diaptomus (Chaetodiaptomus) mirus } \\
\text { Lilljeborg }\end{array}$ & Central-Asian & & + & & & \\
\hline $\begin{array}{c}{ }^{1} \text { Gigantodiaptomus irtyshensis Krupa, } \\
\text { Stuge }\end{array}$ & endemic & & & + & & \\
\hline $\begin{array}{c}{ }^{1} \text { Gigantodiaptomus amblyodon } \\
\text { (Marenzeller) }\end{array}$ & Palaearctic & & & + & & \\
\hline 2 Gigantodiaptomus angularis (Rylov) & Central-Asian & & & + & & \\
\hline${ }^{1}$ Hemidiaptomus ignatovi Sars & Central-Asian & & + & + & & \\
\hline
\end{tabular}


Table 3. Cont.

\begin{tabular}{|c|c|c|c|c|c|c|}
\hline \multirow{3}{*}{ Species Name } & \multirow{3}{*}{$\begin{array}{l}\text { Types of } \\
\text { Species }\end{array}$} & \multirow{3}{*}{$\begin{array}{l}\text { Ponto-Caspian } \\
\text { Region }\end{array}$} & \multicolumn{4}{|c|}{ Palaearctic Region } \\
\hline & & & \multicolumn{3}{|c|}{ ES } & \multirow{2}{*}{$\begin{array}{l}\text { NA } \\
\text { BLH }\end{array}$} \\
\hline & & & VU & IRT & TUR-AR & \\
\hline${ }^{1}$ Eudiaptomus vulgaris (Schmeil) & cosmopolite & & + & + & & \\
\hline${ }^{1}$ Eudiaptomus transylvanicus Daday & Palaearctic & & & + & & \\
\hline${ }^{3}$ Eudiaptomus gracilis (Sars) & Palaearctic & & $+?$ & $+?$ & & \\
\hline${ }^{1}$ Eudiaptomus graciloides (Lilljeborg) & Palaearctic & & + & + & + & + \\
\hline $\begin{array}{c}{ }^{1} \text { Acanthodiaptomus denticornis } \\
\text { (Wierzejski) }\end{array}$ & Palaearctic & & + & + & + & + \\
\hline $\begin{array}{c}{ }^{3} \text { Arctodiaptomus (Arctodiaptomus) } \\
\text { laticeps (Sars) }\end{array}$ & Palaearctic & & & + & & \\
\hline $\begin{array}{c}{ }^{1} \text { Arctodiaptomus (Arctodiaptomus) } \\
\text { dentifer (Smirnov) }\end{array}$ & Palaearctic & & & + & & \\
\hline $\begin{array}{c}{ }^{3} \text { Arctodiaptomus (Arctodiaptomus) } \\
\text { wierzejskii (Richard) }\end{array}$ & Palaearctic & & $+?$ & & & $+?$ \\
\hline $\begin{array}{c}{ }^{2} \text { Arctodiaptomus (Arctodiaptomus) } \\
\text { naurzumensis Stepanova }\end{array}$ & endemic & & & + & & \\
\hline $\begin{array}{c}{ }^{1} \text { Arctodiaptomus (Rhabdodiaptomus) } \\
\text { acutilobatus (Sars) }\end{array}$ & Palaearctic & & & + & & \\
\hline $\begin{array}{c}{ }^{1} \text { Arctodiaptomus (Rhabdodiaptomus) } \\
\text { bacillifer (Koelbel) }\end{array}$ & Palaearctic & & + & + & + & + \\
\hline $\begin{array}{l}{ }^{1} \text { Arctodiaptomus (Rhabdodiaptomus) } \\
\text { salinus (Daday) }\end{array}$ & Palaearctic & + & + & + & + & + \\
\hline $\begin{array}{l}{ }^{3} \text { Arctodiaptomus (Rhabdodiaptomus) } \\
\text { spinosus (Daday) }\end{array}$ & Palaearctic & & $+?$ & & & \\
\hline $\begin{array}{c}{ }^{1} \text { Arctodiaptomus (Rhabdodiaptomus) } \\
\text { ulomskyi Chechura }\end{array}$ & Central-Asian & & + & & & \\
\hline $\begin{array}{c}{ }^{3} \text { Arctodiaptomus (Mesodiaptomus) } \\
\text { lobulifer (Rylov) }\end{array}$ & Caucasus & & & $+?$ & & \\
\hline${ }^{3}$ Mixodiaptomus incrassatus (Sars) & Palaearctic & & & + & & \\
\hline $\begin{array}{l}{ }^{1} \text { Neutrodiaptomus (Neutrodiaptomus) } \\
\text { incongruens (Poppe)* }\end{array}$ & Central-Asian & & & + & & + \\
\hline $\begin{array}{c}{ }^{1} \text { Phyllodiaptomus blanci (Guerne and } \\
\text { Richard) }\end{array}$ & Central-Asian & & + & + & + & + \\
\hline $\begin{array}{l}{ }^{1} \text { Sinodiaptomus (Sinodiaptomus) sarsi } \\
\text { (Rylov) }{ }^{*}\end{array}$ & Palaearctic & & & & + & + \\
\hline $\begin{array}{c}1 \text { Neodiaptomus schmackeri Poppe and } \\
\text { Richard * }\end{array}$ & cosmopolite & & & & + & \\
\hline Total: & & $5(8)$ & $10(15)$ & 20(23) & 8 & $7(8)$ \\
\hline
\end{tabular}

${ }^{*}$ Notes. ${ }^{1}$-the species are indicated based on original drawings and materials of our research; ${ }^{2}$-species suggested based on original descriptions of individuals from water bodies of Kazakhstan [9,32-34]; ${ }^{3}$-species indicated based on published checklists [19,38-45]; 4 - species that have disappeared from the fauna of Kazakhstan. The asterisk marks the invasive species. The number of species is indicated in brackets, taking into account unconfirmed reports. Positive sign—presence of species, positive sign with question mark-unconfirmed reports. Abbreviations. ES-European-Siberian subregion, NA-Nagorno-Asian subregion, VU-Volga-Ural province, IRT-Irtysh province, TUR-AR-Turkestan-Aral province, BLH-Balkhash provinces. 
Table 4. Diversity of species of the order Calanoida in water bodies of Kazakhstan.

\begin{tabular}{|c|c|c|c|c|c|}
\hline Family & Genus & Species Number & Family & Genus & Species Number \\
\hline Acartiidae & Acartia & 1 & & Eudiaptomus & $3(4) *$ \\
\hline Pseudodiaptomidae & Calanipeda & 1 & & Acanthodiaptomus & 1 \\
\hline Centropagidae & Limnocalanus & $(1)^{*}$ & & Arctodiaptomus & $6(10) *$ \\
\hline \multirow{2}{*}{ Temoridae } & Heterocope & 1 & & Mixodiaptomus & $(1)^{*}$ \\
\hline & Eurytemora & $2(6) *$ & & Neutrodiaptomus & 1 \\
\hline \multirow{4}{*}{ Diaptomidae } & Diaptomus & $1(2)^{*}$ & & Phyllodiaptomus & 1 \\
\hline & Metadiaptomus & 1 & & Sinodiaptomus & 1 \\
\hline & Hemidiaptomus & 1 & & Neodiaptomus & 1 \\
\hline & Gigantodiaptomus & 3 & & & \\
\hline
\end{tabular}

${ }^{*}$ Notes. A potentially possible number of species is given in brackets.

Only four species are widespread: Acanthodiaptomus denticornis, Arctodiaptomus (R.) salinus, Phyllodiaptomus blanci, and Eudiaptomus graciloides. The first species is recorded in mountainous ultra-fresh lakes and lowland water bodies, with a TDS of up to $0.5-1.1 \mathrm{~g} / \mathrm{dm}^{3}$. A. (R.) salinus occurs in water bodies with a wide gradient of TDS $\left(0.4-231.7 \mathrm{~g} / \mathrm{dm}^{3}\right)$ and reaches its highest abundance at $4.2-18.0 \mathrm{~g} / \mathrm{dm}^{3}$. P. blanci is found mainly in ponds and small lakes in South and Central Kazakhstan. E. graciloides is recorded both in mountainous ultra-fresh lakes and in lowland lakes and reservoirs and steppe lakes with relatively high water salinity.

Only Metadiaptomus asiaticus can be classified as typical halobionts that avoid fresh and brackish waters [45]. Arctodiaptomus (Rhabdodiaptomus) salinus, Hemidiaptomus ignatovi, Eurytemora affinis, Calanipeda aquaedulcis, Heterocope caspia, Acartia (Acanthacartia) tonsa can withstand significant fluctuations in salinity. C. aquaedulcis inhabits the Caspian and Aral seas, as well as some floodplain lakes in the Syrdarya river. The water of these lakes differs not only in the total salt content but also in chemical composition. The freshwater and brackish-water complex is represented by Eudiaptomus graciloides, E. vulgaris, E. transylvanicus, Acanthodiaptomus denticornis, Neolovenula alluaudi, Neutrodiaptomus (Neutrodiaptomus) incongruens, Diaptomus (Chaetodiaptomus) mirus, Gigantodiaptomus irtyshensis, G. amblyodon, Arctodiaptomus (R.) acutilobatus, A. (R.) bacillifer, A. (R.) ulomskyi, A. (A.) dentifer, Phyllodiaptomus blanci, Sinodiaptomus (Sinodiaptomus) sarsi, Neodiaptomus schmackeri. Most of the species of this complex were found in small, often temporary water bodies with sharp fluctuations in external conditions, which also indicates their euryecy.

Compared to other regions with similar climatic conditions (Uzbekistan, Turkmenia, Tajikistan, partly Israel), the species richness of Calanoida in Kazakhstan is high (Table 5). In addition to the poverty of water resources in arid regions, the Calanoida fauna of adjacent territories remains poorly known. The Calanoida fauna of Russia and China, the closest neighbors of Kazakhstan, with various climatic conditions, are the richest in species. The largest number of common species was found between the Calanoida fauna of Kazakhstan and Ukraine (23), Europe (23), Russia (20), and Romania (13). 
Table 5. Species richness of the Calanoida fauna in countries with different climatic conditions.

\begin{tabular}{|c|c|c|c|}
\hline Country & Prevailing Climate Type * & $\begin{array}{l}\text { Number of } \\
\text { Species }\end{array}$ & $\begin{array}{l}\text { Common Species with the Calanoida Fauna of } \\
\text { Kazakhstan }\end{array}$ \\
\hline Uzbekistan & continental & 6 & $\begin{array}{c}\text { Metadiaptomus asiaticus, Eudiaptomus graciloides, } \\
\text { Acanthodiaptomus denticornis, Phyllodiaptomus } \\
\text { blanci, Arctodiaptomus (R.) salinus }\end{array}$ \\
\hline Turkmenistan & sharply continental & 2 & Neolovenula alluaudi, $A$. (R.) salinus \\
\hline Tajikistan & sharply continental & 3 & Acanthodiaptomus denticornis, P. blanci \\
\hline Mongolia & sharply continental & 7 & $\begin{array}{c}\text { Hemidiaptomus ignatovi, Arctodiaptomus (A.) } \\
\text { wierzjeskii, A. (R.) salinus, M. asiaticus, } \\
\text { Mixodiaptomus incrassatus }\end{array}$ \\
\hline Israel & desert and subtropical & 7 & N. alluaudi, P. blanci, A. (R.) salinus \\
\hline Azerbaijan & subtropical & 8 & $\begin{array}{c}\text { Sinodiaptomus (S.) sarsi, Arctodiaptomus (R.) } \\
\text { acutilobatus }\end{array}$ \\
\hline Georgia & subtropical, Mediterranean & 7 & Arctodiaptomus (R.) bacillifer, A.(R.) acutilobatus \\
\hline Armenia & subtropical & 6 & A. (R.) bacillifer, A.(R.) acutilobatus \\
\hline China & $\begin{array}{l}\text { temperate, subtropical and } \\
\text { monsoon }\end{array}$ & 54 & $\begin{array}{l}\text { A.(R.) salinus, Neutrodiaptomus incongruens, } \\
\text { P. blanci, Neodiaptomus schmackeri }\end{array}$ \\
\hline Russia & $\begin{array}{l}\text { arctic, subarctic, continental, } \\
\text { subtropical }\end{array}$ & 81 & $\begin{array}{c}\text { Calanipeda aquaedulcis, Eurytemora affinis, } \\
\text { Metadiaptomus asiaticus, N. alluaudi, } \\
\text { Hemidiaptomus ignatovi, Eudiaptomus } \\
\text { transylvanicus, E. graciloides, Diaptomus } \\
\text { (Chaetodiaptomus) mirus, Gigantodiaptomus } \\
\text { amblyodon, Gigantodiaptomus angularis, } \\
\text { Acanthodiaptomus denticornis, Arctodiaptomus (A.) } \\
\text { dentifer, A. (R.) acutilobatus, A. (R.) bacillifer, A. (R.) } \\
\text { salinus, A. (R.) ulomskyi, N. (N.) incongruens, } \\
\text { Phyllodiaptomus blanci, Sinodiaptomus (S.) sarsi, } \\
\text { Neodiaptomus schmackeri }\end{array}$ \\
\hline Italy & Mediterranean, subtropical & 60 & $\begin{array}{c}\text { Acanthodiaptomus denticornis, Acartia } \\
\text { (Acanthacartia) tonsa, A. (R.) salinus, Calanipeda } \\
\text { aquaedulcis, Eudiaptomus vulgaris, Mixodiaptomus } \\
\text { incrassatus, N. alluaudi }\end{array}$ \\
\hline Romania & continental & 24 & $\begin{array}{c}\text { Acanthodiaptomus denticornis, Calanipeda } \\
\text { aquaedulcis, Diaptomus (Diaptomus) castor, } \\
\text { Eudiaptomus gracilis, E. graciloides, } \\
\text { E. transylvanicus, E. vulgaris, Eurytemora affinis, } \\
\text { E. lacustris, E. velox, Gigantodiaptomus amblyodon, } \\
\text { Heterocope caspia, N. alluaudi }\end{array}$ \\
\hline Ukraine & continental & 38 & $\begin{array}{c}\text { A. denticornis, Arctodiaptomus (A.) dentifer, } \\
\text { Arctodiaptomus (A.)wierzejskii, Arctodiaptomus } \\
\text { (Rhabdodiaptomus) acutilobatus, A. (R.) bacillifer, A. } \\
\text { (R.) salinus, A. (R.) spinosus, Calanipeda aquaedulcis, } \\
\text { Diaptomus (Diaptomus) castor, Eudiaptomus gracilis, } \\
\text { E.graciloides, E. transylvanicus, E. vulgaris, } \\
\text { Eurytemora affinis, E. grimmi, E. lacustris, E. velox, } \\
\text { Gigantodiaptomus amblyodon, Heterocope caspia, } \\
\text { Metadiaptomus asiaticus, Mixodiaptomus } \\
\text { incrassatus, N. alluaudi, S. (S.) sarsi }\end{array}$ \\
\hline Turkey & continental & 3 & Acanthodiaptomus denticornis, P. blanci, S. (S.) sarsi \\
\hline Europa & $\begin{array}{l}\text { Mediterranean, continental, } \\
\text { temperate oceanic, } \\
\text { subtropical, semi-arid }\end{array}$ & 80 & $\begin{array}{c}\text { A. denticornis, Arctodiaptomus dentifer, } \\
\text { Arctodiaptomus (A.) laticeps, A. (A.)wierzejskii, A. } \\
\text { (R.) bacillifer, A. (R.) salinus, A. (R.) spinosus, C. } \\
\text { aquaedulcis, Diaptomus (Diaptomus) castor, } \\
\text { Eudiaptomus gracilis, E.graciloides, E. } \\
\text { transylvanicus, E. vulgaris, Eurytemora grimmi, } \\
\text { E. lacustris, E. velox, Gigantodiaptomus amblyodon, } \\
\text { Heterocope caspia, Limnocalanus macrurus, } \\
\text { Mixodiaptomus incrassatus, Neolovenula alluaudi, } \\
\text { S. (S.) sarsi }\end{array}$ \\
\hline
\end{tabular}


According to the cluster analysis based on the values of the Bray-Curtis index (Figure 2), the similarity of species composition of more than $50 \%$ revealed only between Kazakhstan and two countries-Romania and Ukraine. About $45 \%$ of the species in the fauna of Kazakhstan were common with countries such as Israel, Turkey, Mongolia, and Uzbekistan. About $40 \%$ of the species identified in the fauna of Kazakhstan were also found in Russia and Europe. The Calanoida fauna of Kazakhstan was significantly different from the Calanoida fauna of China, Italy, Azerbaijan, Georgia, Armenia, Tajikistan, and Turkey.

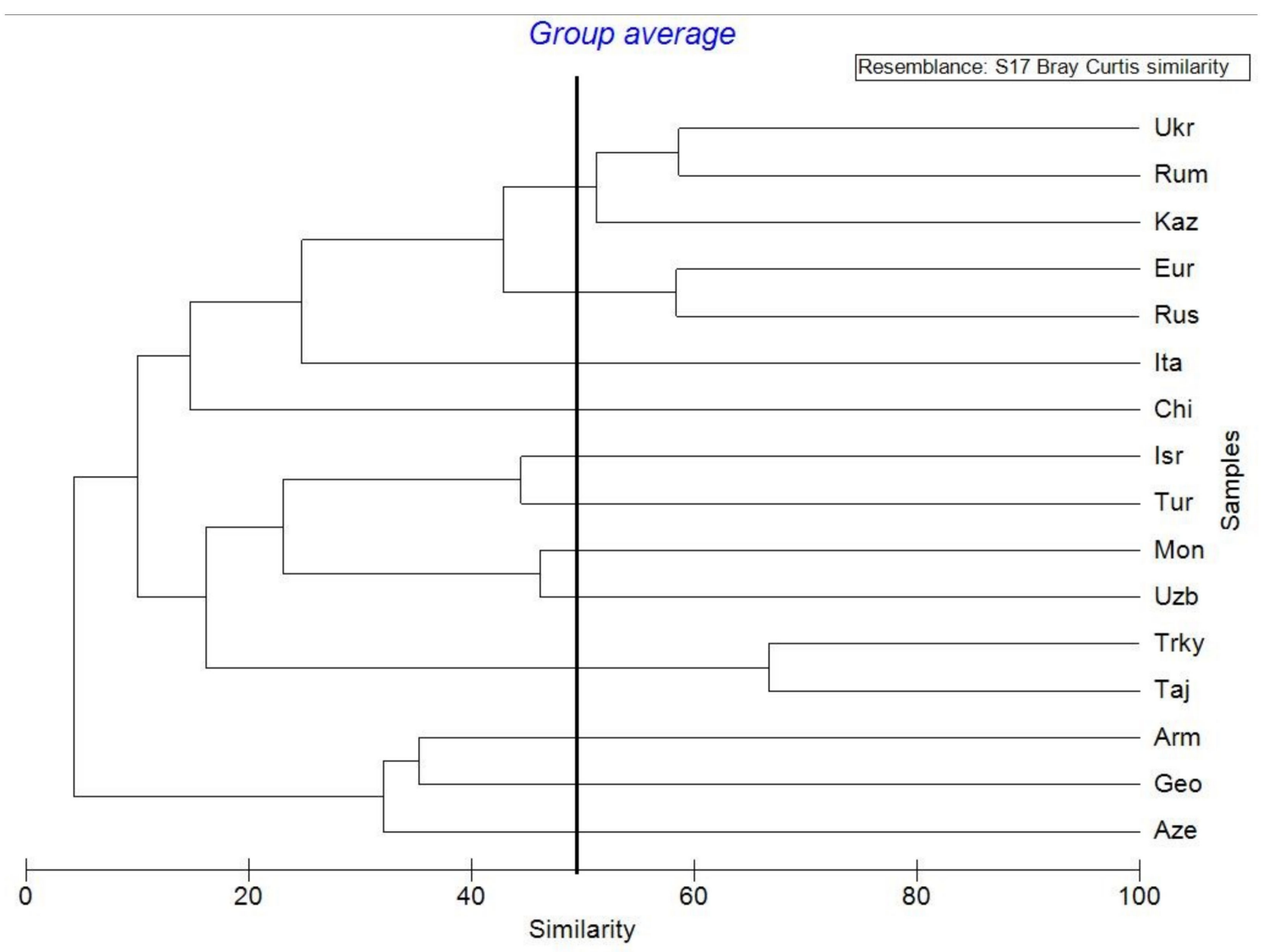

Figure 2. Dendrogram of the similarity of the species composition of Calanoida in countries with different climatic conditions. Abbreviations: Isr-Israel, Tur-Turkmenistan, Mon-Mongolia, Uzb-Uzbekistan, Taj-Tajikistan, Rus—Russia, KazKazakhstan, Chi-China, Arm-Armenia, Geo-Georgia, Aze-Azerbaijan, Trky—Turkey, Ita-Italia, Eur-Europa (in total), Rum-Romania, Ukr-Ukraine.

\section{Discussion}

The finding of 26 species is confirmed by drawings and descriptions made by the authors, as well as those available in publications $[9,13,23,24,32-34]$. Literature sources [38-45] provide information on the findings of the other nine species. Some of them (Eurytemora velox, Arctodiaptomus (Arctodiaptomus) wierzejskii, Arctodiaptomus (Rhabdodiaptomus) spinosus, Arctodiaptomus (Mesodiaptomus) lobulifer) were mentioned only once, almost a hundred years ago [38,39]. Their presence in the region is potentially possible but not documented. Three species (Limnocalanus macrurus, Eurytemora grimmi, Eurytemora minor) were previously encountered in the Caspian Sea [40,56]. They disappeared after 1996 due to the appearance of the ctenophore Mnemiopsis leidyi (A. Agassiz) [57]. None of these species had been found in the Middle and North Caspian in 2006-2016 [58].

Of the total number of species, five are non-native. Three of them (Sinodiaptomus (Sinodiaptomus) sarsi, Neutrodiaptomus (Neutrodiaptomus) incongruens, Neodiaptomus schmackeri are representatives of the Far Eastern complex [28]. S. (S.) sarsi and N. (N.) incongruens 
were found in the water bodies of the southern and southeastern parts of Kazakhstan more than 30 years ago [59]. N. schmackeri was first discovered in the Shardara reservoir (South Kazakhstan) in 2003 and 2007 [60]. Later it was recorded in the lower reaches of the Syrdarya River before its confluence with the Small Aral. This species of Calanoida most likely entered the water bodies of Kazakhstan with fish imported from the Far East [61]. In 1998 S. (S.) sarsi is indicated for Turkey [55] and in 2016 for Ukraine [50]. N. schmackeri entered Europe similarly due to the introduction of fish from Asia to Albania [36].

Calanipeda aquaedulcis and Acartia (Acanthacartia) tonsa entered the Caspian Sea from the Black Sea with the ballast waters of ships, respectively, in 1905 and 1981. In the 1950s, C. aquaedulcis was introduced into the Aral Sea to improve its food supply [61]; it survived the salinization of the Sea and is currently the dominant species in zooplankton. A. (A.) tonsa has long been mistakenly identified as $A$. (Acartiura) clausi [62]. Our long-term studies of the zooplankton of the Caspian Sea confirmed the occurrence of $A$. (A.) tonsa in it [58]. Confusion in the definition of these closely related species could arise in connection with the morphological variability of individuals. According to our studies, male $A$. (A.) tonsa from the northeastern Caspian Sea are distinguished by the presence of a small, rounded projection armed with a spine in the proximal part of the 2nd article of the fifth leg [63]. In individuals from the Middle Caspian, this protrusion is absent or weakly visible. In males of the closely related species $A$. (A.) clausi, the 2 nd article of the right leg of the fifth pair has a large, rounded projection in the distal part.

Endemic species Eurytemora caspica [13], Gigantodiaptomus irtyshensis [10], and Arctodiaptomus (Arctodiaptomus) naurzumensis [9] are still known only from typical habitats: the northern part of the Caspian Sea, a small lake in the floodplain of Irtysh river (East Kazakhstan) and Naurzum lakes (North Kazakhstan). Eight more species are also rare. Diaptomus (Chaetodiaptomus) mirus, Eudiaptomus transylvanicus, Arctodiaptomus (Arctodiaptomus) dentifer, and Arctodiaptomus (Rhabdodiaptomus) ulomskyi were found in small steppe water bodies of western Kazakhstan on the border with Russia. The invader Neodiaptomus schmackeri is known from the Syrdarya River and Shardara reservoir. According to our data [64], Eurytemora affinis is mainly found in the basin of the Nura River (Central Kazakhstan), less often in the middle reaches of the Irtysh River. Metadiaptomus asiaticus inhabits water bodies of Northern and Eastern Kazakhstan with TDS of 5.9-343.3 g/ $\mathrm{dm}^{3}$ [45]. We found Arctodiaptomus (Rhabdodiaptomus) bacillifer only in a small floodplain lake situated in Lake Balkhash basin. Repeated indications of the finding of this species in water bodies of Kazakhstan with high TDS require confirmation since it is often confused with $A$. (R.) salinus and A. (R.) acutilobatus [64].

The composition of the Calanoida fauna is determined by regional climatic conditions that affect the density of the hydrographic network, temperature, and water salinity. The arid climate of most of Kazakhstan determines the occurrence of a significantly smaller number of water bodies compared to humid zones. The predominance of euryecious or euryhaline Calanoida species, adapted to changing external conditions, is associated with pronounced fluctuations in temperature and TDS of water in Kazakhstan [65].

In addition to paleoclimatic factors [66], the distribution of the species' richness of Calanoida by zoogeographic provinces reflects the regional and climatic features of various regions of Kazakhstan. The density of the river network and the number of water bodies connected with rivers is one of the factors in the formation of the species' richness of the fauna of arid territories [67]. The largest number of Calanoida species in the Irtysh province (Table 3) is due to the good water supply in the territory, various climate types, and types of aquatic ecosystems. Most of the water bodies, primarily fresh, are concentrated in the eastern part of its territory. In the northern region, in addition to fresh and brackish lakes, there are many hyperhaline lakes. The central part has the smallest number of water bodies, among which the Korgalzhyn lakes are the most significant, with a water salinity of $1.1-154.6 \mathrm{~g} / \mathrm{dm}^{3}$ [68]. More impoverished fauna in other zoogeographic provinces is associated with poor water resources. 
The originally poor composition and originality of the fauna of the Ponto-Caspian region are associated with its complex origin and the specific chemical composition of the water of the Caspian Sea. Currently, only four species have been reliably recorded here, including the invasive species Acartia (Acanthacartia) tonsa and Calanipeda aquaedulcis, the autochthonous Heterocope caspia [69], and endemic species Eurytemora caspica [13]. As mentioned above, three autochthonous species (Limnocalanus macrurus, Eurytemora grimmi, Eurytemora minor) have not been recorded in the zooplankton of the Caspian Sea for several decades. In addition to the negative influence of the ctenophore Mnemiopsis leidyi [57], their disappearance may be due to competitive displacement by the more eurybiontic invaders Acartia and Calanipeda.

According to cluster analysis (Figure 2), over 50\% of common species have been identified for Kazakhstan, Romania, and Ukraine; about $45 \%$ of common species with Israel, Turkey, Mongolia, and Uzbekistan; about $40 \%$ of species are found in Russia and European countries (including the European part of Russia). Kazakhstan Calanoida was characterized by a low level of similarity with countries such as China, Italy, Azerbaijan, Georgia, Armenia, Tajikistan, and Turkey. The results obtained are associated with both the climatic features of the compared territories and with a different degree of knowledge of the fauna of the order in different countries.

As can be seen from Table 5, the Calanoida fauna of Kazakhstan was closest to the fauna of countries with a continental climate and most strongly differed from countries with subtropical and Mediterranean climates. Comparison of our results is difficult due to the lack of complete lists of Calanoida species for Azerbaijan, Georgia, Armenia, and Tajikistan.

\section{Conclusions}

There are 26 species of Calanoida registered in Kazakhstan. A comparison of the pattern of species diversity showed that the richest in species composition (20) is the Calanoida fauna of the Irtysh province. In the Volga-Ural province, ten species were recorded, in the Turkestan-Aral province-eight, in the Balkhash province-seven, and in the Ponto-Caspian region-six. Acanthodiaptomus denticornis, Arctodiaptomus (Rhabdodiaptomus) salinus, Phyllodiaptomus blanci and Eudiaptomus graciloides are found everywhere. Five species are invaders. Far Eastern Sinodiaptomus (Sinodiaptomus) sarsi, Neutrodiaptomus (Neutrodiaptomus) incongruens, Neodiaptomus schmackeri entered Kazakhstan, most likely with fish; Acartia (Acanthacartia) tonsa and Calanipeda aquaedulcis-with ships' ballast water. Along with Mnemiopsis leydyi, the copepods that entered the Caspian Sea could contribute to the extinction of the autochthonous species Limnocalanus macrurus, Eurytemora grimmi, and Eurytemora minor. Eurytemora caspica, Gigantodiaptomus irtyshensis, Arctodiaptomus (Arctodiaptomus) naurzumensis, Diaptomus (Chaetodiaptomus) mirus, Eudiaptomus transylvanicus, Arctodiaptomus (A.) dentifer are currently known to have a limited area of distribution. The description of endemic Calanoida species and the species new for the region, mainly from small water bodies, testifies the important role of this category of water bodies in maintaining biological diversity. The results obtained contribute to the knowledge of the Calanoida fauna of regions with a continental climate. The revealed similarities and differences of the Calanoida fauna are associated both with the climatic features of the compared territories and with a different degree of knowledge of the fauna of the order in different countries.

Author Contributions: E.K. collected specimens, performed analyses, wrote and edited the manuscript. M.A. participated in data analysis. All authors have read and agreed to the published version of the manuscript.

Funding: The work was carried out under project No. AP08855655, Institute of Zoology, the Committee of Science, Ministry of Education and Science, Republic of Kazakhstan "Assessment of the ecological state of wastewater reservoirs of the system of the Right-Bank Sorbulak Canal for the development of the scientific basis for wastewater disposal".

Institutional Review Board Statement: Not applicable.

Informed Consent Statement: Not applicable. 
Data Availability Statement: No new data were created or analyzed in this study. Data sharing is not applicable to this article.

Conflicts of Interest: The authors declare no conflict of interest.

\section{References}

1. Hernández-León, S.; Ikeda, T. A global assessment of mesozooplankton respiration in the ocean. J. Plankton Res. 2005, 27, 153-158. [CrossRef]

2. Kobari, T.; Steinberg, D.; Ueda, A.; Tsuda, A.; Silver, M.; Kitamura, M. Impacts of ontogenetically migrating copepods on downward carbon flux in the western Subarctic Pacific Ocean. Deep Sea Res. Part II Top. Stud. Oceanogr. 2008, 55, 1648-1660. [CrossRef]

3. Yamaguchi, A.; Matsuno, K.; Homma, T. Spatial changes in the vertical distribution of calanoid copepods down to great depths in the North Pacific. Zool. Stud. 2015, 54, 13. [CrossRef]

4. Dussart, B.; Defaye, D. World Directory of Crustacea Copepoda of Inland Waters: Calaniformes; Backhuys: Leiden, The Netherlands, 2002; p. 276.

5. Luong, T.D.; Hai, H.; Thanh, D.N. An annotated checklist of the family Diaptomidae Sars, 1903 (Copepoda, Calanoida) in Vietnam. Acad. J. Biol. 2016, 38, 384-400. [CrossRef]

6. Boxshall, G.A.; Defaye, D. Global diversity of copepods (Crustacea: Copepoda) in freshwater. Hydrobiologia 2008, 595, 195-207. [CrossRef]

7. Boxshall, G.A.; Jaume, D. Making waves: The repeated colonization of freshwater by copepod crustaceans. Adv. Ecol. Res. 2000, 31, 61-79.

8. Marrone, M.; Petrusek, A.; Alfonso, G.; Arculeo, M. The diaptomid fauna of Israel (Copepoda, Calanoida, Diaptomidae), with notes on the systematics of Arctodiaptomus similis (Baird, 1859) and Arctodiaptomus irregularis Dimentman \& Por, 1985. Zool. Stud. 2014, 53, 74 .

9. Stepanova, L.A. Arctodiaptomus (Arctodiaptomus) naurzumensis n. sp. (Copepoda, Calanoida) from Kazakhstan. Hydrobiologia 1994, 288, 129-134. [CrossRef]

10. Krupa, E.G.; Stuge, T.S. New species of the genus Gigantodiaptomus (Copepoda, Calanoida) from Northeastern Kazakhstan. Bull. Natl. Acad. Sci. 2007, 1, 18-22.

11. Sukhikh, N.M.; Alekseev, V.R. Eurytemora caspica sp. nov. from the Caspian Sea-one more new species within the E. affinis complex (Copepoda: Calanoida: Temoridae). Proc. Zool. Inst. Natl. Acad. Sci. 2013, 317, 85-100.

12. Fefilova, E.; Sukhikh, N.; Abramova, E.; Velegzhaninov, I. About the systematics of palaearctic Eurytemora (Copepoda, Calanoida) based on morphological analysis, with focus on Eurytemora gracilicauda Akatova, 1949. Crustaceana 2019, 93, 299-315. [CrossRef]

13. Sukhikh, N.A.; Souissi, S.; Souissi, A.C.; Holl, N.; Alekseev, V. Life in sympatry: Coexistence of native Eurytemora affinis and invasive Eurytemora carolleeae in the Gulf of Finland (Baltic Sea). Oceanologia 2019, 61, 227-238. [CrossRef]

14. Mirabdullayev, I.M.; Ismoilov, H.; Abdinazarov, H.; Kuzmetov, A.R. On fauna of Calanoida (Copepoda, Crustacea) of Uzbekistan. Sci. J. Far East. Fish Tech. Univ. 2012, 27, 45-47.

15. Dobrokhotova, O.V. Parasite-host system "larvae of hymenolipedids-Copepods and ostracods" in water bodies of Kazakhstan. Proc. Inst. Zool. 1984, 41, 37-152.

16. Lepeshkin, V.D. On the fauna of Copepoda. Proc. Imp. Soc. Lovers Nat. Sci. Anthropol. Ethnogr. 1900, 98, $21-31$.

17. Zernov, S.A. On the animal plankton of the Aral Sea rivers based on materials collected by L.S. Berg in 1900. Bull. Turkestan Branch Russ. Geogr. Soc. 1903, 1, 1-38.

18. Bening, A.L.; Medvedev, N.B. On the microfauna of the surroundings of lakes Elton and Baskunchak. In Archaeology at the Saratov State University and the Lower Volga Institute for Local Studies at the Turn of Epochs; Gidrometeoizdat: Leningrad, Russia, 1926 ; p. 39.

19. Bening, A.L. Materials on the hydrobiology of the Ural river. In Big Emba; Academy of Sciences of the Kazakh SSR: Alma-Ata, Kazakhstan, 1938; p. 257.

20. Tseb, J.J. To the knowledge of the fauna of the lakes of Northern Kazakhstan in connection with their fishery assessment. Sci. Notes Orel State Univ. 1940, 1, 37-87.

21. Dobrokhotova, O.V. Fauna of Calanoida (Copepoda) in Kazakhstan and their participation in the circulation of hymenolipedids of aquatic birds. Fauna, biology, and zoogeography of animal helminths in Kazakhstan. Proc. Inst. Zool. 1979, 581, 55-88.

22. Krupa, E.G.; Stuge, T.S.; Troshina, T.T. Results of the Inventory of the Fauna of Copepods (Copepoda: Cyclopoida, Calanoida) in Kazakhstan. In Some Aspects of Hydroecological Problems in Kazakhstan; Kaganat: Alma-Ata, Kazakhstan, $2011 ;$ p. 257.

23. Krupa, E.G. Diversity and quantitative variables of zooplankton in small water bodies of the West Kazakhstan region. Bull. Kazakh Natl. Univ. 2012, 1, 182-185.

24. Krupa, E.; Barinova, S. Diaptomus (Chaetodiaptomus) mirus Lilljeborg in Guerne Et Richard, 1889-New species of Calanoida (Crustacea: Copepoda) in the fauna of Kazakhstan. Bull. Natl. Acad. Sci. Repub. Kazakhstan 2015, 5, 21-26.

25. Baidal, M.H. Long-Term Weather Forecasts and Climate Variations in Kazakhstan; Gidrometeoizdat: Leningrad, Russia, $1964 ;$ p. 312.

26. Frumin, G.T.; Krashanovskaya, Y.V. Assessment of the trophic status of the lakes of Kazakhstan. Ecol. Chem. 2014, 23, 8-12.

27. Starobogatov, L. Fauna of Mollusks and Zoogeographic Zoning of Continental Water Bodies; Russian Academy of Sciences: Leningrad, Russia, 1970; p. 372. (In Russian) 
28. Borutsky, E.V.; Stepanova, L.A.; Koss, M.S. Determinant for Calanoida in Fresh Waters of the USSR; Russian Academy of Sciences: St. Petersburg, Russia, 1991; 504p.

29. Reddy, Y.R. Copepoda: Calanoida: Diaptomidae. In Key to the Genera Heliodiaptomus, Allodiaptomus, Neodiaptomus, Phyllodiaptomus, Eodiaptomus, Arctodiaptomus and Sinodiaptomus; Academic Publishing: St. Petersburg, Russia, 1994; p. 222.

30. Chechuro, E.G. On new species Arctodiaptomus from the ponds of Om region. J. Zool. 1960, 39, 1730-1732.

31. Kurasheva, E.K.; Abdullaeva, N.M. Acartia tonsa (Calanoida, Acartiidae) in the Caspian Sea (misidentified as A. clausi). J. Zool. 1984, 63, 929-930.

32. Stepanova, L.A. On the composition of the genus Hemidiaptomus: Isolation of Gigantodiaptomus and Occidodiaptomus (Crustacea, Diaptomidae) as independent genera. J. Zool. 2005, 84, 754-760.

33. Stepanova, L.A.; Aladin, N.V.; Plotnikov, I.S. New subspecies Hemidiaptomus ignatovi (Crustacea, Diaptomidae) from Kyrgyzstan. J. Zool. 2009, 88, 243-246.

34. Alekseev, V.R.; Soussi, A. A new species within the Eurytemora affinis complex (Copepoda: Calanoida) from the Atlantic Coast of USA, with observations on eight morphologically different European populations. Zootaxa 2011, 2767, 41-56. [CrossRef]

35. Alfonso, G.; Belmonte, G. Neolovenula alluaudi (Guerne and Richard, 1890) (Calanoida: Diaptomidae: Paradiaptominae): First record in Italy and review of geographical distribution. J. Limnol. 2013, 72, 251-261. [CrossRef]

36. Alfonso, G.; Russo, R.; Belmonte, G. First record of the Asian diaptomid Neodiaptomus schmackeri (Poppe \& Richard, 1892) (Crustacea: Copepoda: Calanoida) in Europe. J. Limnol. 2014, 73, 584-592.

37. Clarke, K.R.; Gorley, R.N. PRIMER v5: User Manual/Tutorial; PRIMER-E Ltd. Press: Plymouth, UK, 2001.

38. Zykoff, W. Über das Plankton des Saisan-See. Zool. Anz. 1905, 29, 477-482.

39. Keizer, N. To the fauna of Copepoda and Cladocera of Syrdarya River and its coastal water bodies. Bull. Cent. Asian Univ. 1923, 2, 61-67.

40. Kun, M.S. Copepods, Atlas of Invertebrates of the Caspian Sea; The Food Industry: Moscow, Russia, $1968 ;$ p. 411.

41. Pilguk, V.Y. Zooplankton of Zaysan Lake. Proc. Kazakh Res. Inst. Fish. 1996, 5, 255-264.

42. Kasymov, A.G. Fauna of the Caspian Sea; Elim: Baku, Azerbaijan, 1987; 156p.

43. Hossieni, A.; Roohi, A.; Ganjian, K.A.; Roshantabari, M.; Hashemian, A.; Solimanroudi, A.; Nasrollazadeh, H.S. Hydrology and Hydrobiology of the Southern Caspian Sea; Iranian Fisheries Research Organization (IFRO): Tehran, Iran, 1996 ; p. 510.

44. Stuge, T.S.; Devyatkov, V.I. Zooplankton of Lake Markakol. Proc. Markakol Reserve 2008, 1, 48-59.

45. Stuge, T.S. Distribution of Metadiaptomus asiaticus (Uljanin, 1875) (Copepoda: Calanoida) in water bodies of Kazakhstan. In Proceedings of the Biodiversity of Fauna in Kazakhstan, Problems of Conservation and Use, Almaty, Kazakhstan, 5-8 June 2007; pp. 73-75.

46. Khaitov, A. Formation of the Fauna of Zooplankton in the Reservoirs of Southern Tajikistan; Zinatov: Dushanbe, Tajikistan, 2011; 33p.

47. Li, H.; Henri, J.; Dumont, B.P.; Han, F.; Lin, Q. Updated checklist and distribution of the diaptomid copepods (Copepoda, Calanoida, Diaptomidae) of China. Crustaceana 2018, 91, 335-352. [CrossRef]

48. Alonso, M. Branchiopoda and Copepoda (Crustacea) in Mongolian Saline Lakes. Mong. J. Biol. Sci. 2010, 8, 9-16.

49. Samchyshyna, L. Faunistical overview of Calanoid copepods (crustacea) from continental waters of Ukraine. Vestn. Zool. 2011, 45, 9-15. [CrossRef]

50. Mykitchak, T. Checklist and distribution of Cladocera and Copepoda (Calanoida, Cyclopoida) from the Ukrainian Carpathians. J. Wetl. Biodivers. 2016, 6, 109-112.

51. Demeter, L.; Marrone, F. Updated checklist and distribution of the inland-water calanoid copepods (Copepoda: Calanoida) of Romania North-Western. J. Zool. 2009, 5, 370-378.

52. Belmonte, G.; Alfonso, G.; Moscatello, S. Copepod fauna (Calanoida and Cyclopoida) in small ponds of the Pollino National Park (South Italy), with notes on seasonality and biometry of species. J. Limnol. 2006, 65, 107-113. [CrossRef]

53. Belmonte, G. Calanoida (Crustacea: Copepoda) of the Italian fauna: A review. Eur. Zool. J. 2018, 85, 1273-1289. [CrossRef]

54. Błędzki, L.A.; Rybak, J.I. Freshwater Crustacean Zooplankton of Europe Cladocera and Copepoda (Calanoida, Cyclopoida) Key to species identification, with notes on ecology, distribution, methods and introduction to data analysis. In Alphabetical List of Species with Notes on Synonyms, Taxonomy, Distribution, and Ecology; Springer International Publishing: Switzerland, Cham, 2016; pp. $475-552$.

55. Gündüz, E. Sinodiaptomus sarsi (Rylov, 1923) (Copepoda, Calanoida) in Turkey. Hydrobiologia 1998, 380, 9-13. [CrossRef]

56. Osmanov, M.M.; Aligadzhiev, M.M.; Amaeva, F.S.H. Features of the vertical distribution of zooplankton in the Middle Caspian. Proc. Dagestan State Pedagog. Univ. 2009, 1, 3-9.

57. Roohi, A.; Kideys, A.E.; Sajjadi, A.; Hashemian, A.; Pourgholam, R.; Fazli, H.; Khanari, A.G.; Eker-Develi, E. Changes in biodiversity of phytoplankton, zooplankton, fishes, and macrobenthos in the Southern Caspian Sea after the invasion of the ctenophore Mnemiopsis leidyi. Biol. Invasions 2010, 12, 2343-2361. [CrossRef]

58. Krupa, E.; Kokhno, L.; Kiyko, O. Zooplankton. In Environmental Monitoring Studies of the Environment of the North-Eastern Caspian During the Development of oil Fields by NCOC in the Period from 2006 to 2016; Skolsky, V.A., Ed.; North Caspian Operating Company NCOC: Almaty, Kazakhstan; Kazakhstan Agency of Applied Ecology (KAPE): Almaty, Kazakhstan, 2018 ; p. 400.

59. Sharapova, L.I.; Orlova, N.R. The main features of zooplankton communities in the Kapchagai reservoir in the first years of its filling. Biol. Sci. 1975, 9, 16-28. 
60. Krupa, E. Neodiaptomus schmackeri (Poppe et Richard, 1892)—The new species of Calanoida (Copepoda: Crustacea) in Kazakhstan and Central Asia. Bull. Natl. Acad. Sci. 2015, 5, 36-40.

61. Karpevich, A.F. Theory and Practice of Acclimatization of Aquatic Organisms; Food Industry: Moscow, Russia, $1975 ;$ p. 431.

62. Prusova, I.Y.U.; Gubanova, A.D.; Shadrin, N.V.; Kurasheva, E.K.; Tinenkova, D.K.H. Acartia tonsa (Copepoda, Calanoida)—A new species in the zooplankton of the Caspian and Azov seas. Bull. Zool. 2002, 36, 65-68.

63. Krupa, E.; Dobrokhotova, O.V.; Stuge, T.S. Fauna Calanoida (Crustacea, Copepoda) of Kazakhstan and Adjacent Territories; EtalonPrint: Almaty, Kazakhstan, 2016; p. 208.

64. Krupa, E.G. The ecological preferences of Eurytemora affinis (Poppe, 1880) in the Kazakhstan's water bodies (Central Asia). Crustaceana 2020, 93, 405-428. [CrossRef]

65. Romanova, S.M. Non-Drainage Reservoirs of Kazakhstan. Hydrochemical Regime; KazNU: Almaty, Kazakhstan, 2008 ; p. 224.

66. Marrone, F.; Alfonso, G.; Naselli-Flores, L.; Stoch, F. Diversity patterns and biogeography of Diaptomidae (Copepoda, Calanoida) in the Western Palearctic. Hydrobiologia 2017, 800, 45-60. [CrossRef]

67. Dubrovsky, V.Y. River systems of humid zones and similar formations in arid zones contribute to the formation of species richness of faunas in natural zones (for example, small mammals). Bull. Mosc. Soc. Nat. 2014, 119, 3-12.

68. Slivinsky, G.G.; Krupa, E.G. The current state of the Teniz-Korgalzhyn lakes in terms of hydrochemical and toxicological indicators. Bull. Kazakh Natl. Univ. 2013, 1, 74-81.

69. Mordukhai-Boltovskoy, F.D. Caspian Fauna in the Azov-Black Sea Basin; USSR Academy of Sciences Publishing House: Moscow, Russia, 1960; p. 400. 